\title{
Differential expression of miR-4520a is associated with gain of function mutations in Familial Mediterranean Fever (FMF)
}

\author{
H Latsoudis', MF Mashreghi ${ }^{2}$, J Gruen ${ }^{3}$, H-D Chang ${ }^{2}$, B Stuhlmueller ${ }^{4}$, A Repa ${ }^{5}$, I Gergiannaki ${ }^{5}$, E Kabouraki ${ }^{5}$, \\ P Papakosta ${ }^{6,7}$, T Haeupl $^{4}$, A Radbruch ${ }^{2}$, P Sidiropoulos ${ }^{1,5}$, D Kardassis ${ }^{6,7}$, D Boumpas ${ }^{7,8}, G$ Goulielmos ${ }^{1 *}$ \\ From 8th International Congress of Familial Mediterranean Fever and Systemic Autoinflammatory Diseases \\ Dresden, Germany. 30 September - 3 October 2015
}

\section{Introduction}

MicroRNA signature of THP1 cells revealed a 5.9-fold decreased expression of miR-4520a following siRNAmediated knockdown of $M E F V$ gene that encodes pyrin [1].

\section{Objectives}

We herein sought to validate the expression levels of miR-4520a in monocytes isolated from peripheral blood mononuclear cells (PBMCs) of FMF patients.

\section{Methods}

Dual luciferase assay was used to validate a predicted miR-4520a recognition element in the 3'UTR region of the Rheb gene. The expression levels of pyrin, miR$4520 \mathrm{a}$ and its putative target Rheb were validated in monocytes from FMF patients $(n=9)$ and compared with healthy controls $(n=8)$. Patients were off colchicine for two days (attack-free period) and monocytes were isolated from PBMCs. Total RNA together with the respective miRNA-enriched fractions were isolated from monocytes and used for mRNA and miR-4520a quantitation by real-time PCR using the $2-\Delta \Delta \mathrm{Ct}$ method after normalizing to $18 \mathrm{~S}$ RNA and RNU6B genes, respectively. Protein levels of pyrin and Rheb were detected by western blotting.

\section{Results}

The relative expression levels of miR-4520a were variable among FMF patients and not significantly different between patients and controls. However, when patients

\footnotetext{
${ }^{1}$ University of Crete, Medical School, Internal Medicine, Heraklion, Greece Full list of author information is available at the end of the article
}

that did not harbor any mutations in $M E F V$ were excluded from the analyses, the expression of miR4520a was statistically different between FMF patients and controls $(\mathrm{p}<0.05)$, indicating an association between miR-4520a expression and mutations in the $M E F V$ gene. Moreover, stratification of patients group by genotype revealed an intriguing difference in miR-4520a relative expression, with carriers of M694V variant (combined group of homozygotes, heterozygotes and compound heterozygotes) showing the highest increase $(\mathrm{p}<0.05)$. Subsequent comparison between the M694V group and healthy controls showed a significant increase in miR4520a expression levels that remained significant even after bonferroni correction $(\mathrm{p}<0.01)$. Interestingly, one of the homozygote $\mathrm{M} 694 \mathrm{~V}$ patients with the highest fold change in miR-4520a expression $(\mathrm{FC}=7.8)$ experienced an FMF-attack while on study, with a concomitant decrease in miR-4520a relative expression $(F C=0.45)$. Bio-informatic analyses showed that miR$4520 \mathrm{a}$ is predicted to target genes implicated in autophagy through regulation of Rheb/mTOR signaling. Expression levels of Rheb were confirmed by luciferase reporter gene assays providing further evidence that Rheb is a direct target of miR-4520a $(\mathrm{p}<0.01)$. Validation of pyrin and Rheb protein expression levels in monocytes from FMF patients is in progress.

\section{Conclusion}

Our findings provide initial evidence that Rheb is a valid target of miR-4520a and suggest that a dysfunctional pyrin due to gain of function mutations with a dosage effect [2], especially of M694V variant, may be associated with an increase in miR-4520a expression levels, 
thus contributing to deregulated mTOR signaling and subsequently IL- $1 \beta$ release [3].

\section{Authors' details}

${ }^{1}$ University of Crete, Medical School, Internal Medicine, Heraklion, Greece.

${ }^{2}$ German Rheumatism Research Center (DRFZ), Berlin, Germany. ${ }^{3}$ German

Rheumatism Research Center (DRFZ), Bioinformatics, Berlin, Germany.

${ }^{4}$ Charité University Hospital, Rheumatology and Clinical Immunology, Berlin,

Germany. ${ }^{5}$ University Hospital of Heraklion, Clinic of Rheumatology,

Heraklion, Greece. ' University of Crete, Medical School, Biochemistry,

Heraklion, Greece. ${ }^{7}$ Institute of Molecular Biology and Biotechnology,

Foundation for research and Technology of Hellas, Heraklion, Greece.

${ }^{8}$ University of Athens, Medical School, Athens, Greece.

Published: 28 September 2015

\section{References}

1. Mashreghi M F, Latsoudis H, Gruen J, et al: Ann Rheum Dis 2014, 73:344-345.

2. Chae J J, Cho Y-H, Lee G-S, et al: Immunity 2011, 34:755-768.

3. Schmitz F, Heit A, Dreher S, et al: Eur J Immun 2008, 38:2981-2992.

doi:10.1186/1546-0096-13-S1-010

Cite this article as: Latsoudis et al:: Differential expression of miR-4520a

is associated with gain of function mutations in Familial Mediterranean

Fever (FMF). Pediatric Rheumatology 2015 13(Suppl 1):010.

\section{Submit your next manuscript to BioMed Central} and take full advantage of:

- Convenient online submission

- Thorough peer review

- No space constraints or color figure charges

- Immediate publication on acceptance

- Inclusion in PubMed, CAS, Scopus and Google Scholar

- Research which is freely available for redistribution

Submit your manuscript at www.biomedcentral.com/submit
C BioMed Central 